Actes des congrès de la Société française

Shakespeare et la peur

\title{
Fear and the Other in Sir Thomas More
}

Sean Lawrence

\section{(2) OpenEdition}

Journals

Édition électronique

URL : https://journals.openedition.org/shakespeare/4123

DOI : 10.4000/shakespeare.4123

ISSN : 2271-6424

Éditeur

Société Française Shakespeare

\section{Référence électronique}

Sean Lawrence, "Fear and the Other in Sir Thomas More ", Actes des congrès de la Société française Shakespeare [En ligne], 36 | 2018, mis en ligne le 04 avril 2018, consulté le 25 août 2021. URL : http:// journals.openedition.org/shakespeare/4123; DOI : https://doi.org/10.4000/shakespeare.4123

Ce document a été généré automatiquement le 25 août 2021.

(c) SFS 


\title{
Fear and the Other in Sir Thomas
}

\section{More}

\author{
Sean Lawrence
}

Fear pervades the plot, the critical history, the contemporary reception and even the form of the surviving manuscript of the collaborative play Sir Thomas More. Fearing the reaction of Londoners to the theatrical representation of a xenophobic riot, Edmund Tilney, the Master of the Revels, scribbled his judgement at the beginning of the manuscript: "Leave out the insurrection wholly and the cause thereof." He threatens the authors, allowing them to mention the rebellion "only by a short report, and not

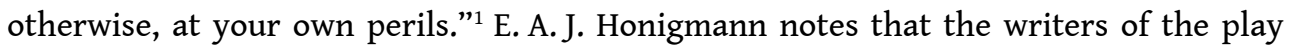
assigned William Shakespeare "One scene [which] needed to be written with particular care," where More must calm the rebels. Honigmann considers Shakespeare's three pages to be important because "they demonstrate the quality of More's mind and personality" but they would also constitute the most politically sensitive scene in the play. ${ }^{2}$ Honigmann also judges that "the writing of the Three Pages was an act of considerable courage," on Shakespeare's part. ${ }^{3}$ Certainly, all of the writers would have been correct to fear censorship or even their "own perils." Fear, in other words, might not only be the reason that the play was neither printed nor produced for hundreds of years, but also the reason that Shakespeare was included in the project at all.

2 Tilney was not the first authority to fear the fictive rebellion. Within the excised scenes themselves, Surrey remarks that "This tide of rage, that with the eddy strives, / I fear me much will drown too many lives" (3.62-63). Fear not only of popular violence but also of the state hangs over the characters of the play. This latter finds expression in the beheading of the title character, as well as the hanging of John Lincoln and nearhanging of the other rebels. Fear of "the strangers" drives the rebellion, and the strangers, in turn, fear the rebels. According to the clown, the strangers even "smell for fear" (4.47-48). More's wife cries "Oh, God, I fear, I fear" when the Earls of Surrey and Shrewsbury arrive (13.129). More raises the spectre of fear in his last line, even while denying his own: "Our birth to heaven should be thus: void of fear" (17.124). The play broaches a broader question of the role of fear in politics, beyond all these particular 
fears expressed in the play itself and manifested by those who wrote, revised or finally suppressed it. By adding the scene in Hand D, Shakespeare shifts the focus of the audience and of the play as a whole from fear of the other to fear for the other.

3 Tilney's fears were by no means misplaced. Eric Griffin notes that "Tilney had presciently gauged the pulse of London's merchant and artisan resentments," expressed in the so-called Dutch Church Libel published at roughly the same time. This bill refers to the works of Marlowe, in its promise to cause English events on the scale of the "Paris massacre" and reference to Tamburlaine. ${ }^{4}$ Stage violence risked inspiring off-stage imitation. Tilney's strong warning inspired fear among the playwrights who generated the script, evident in the fact that the play remained unstaged until an amateur production at Birkbeck College in 1922. ${ }^{5}$ By 1923 "the play's significance to the study of Shakespeare had been fully established." ${ }^{\prime}$ Due to its late, partial and somewhat ambiguous admission into Shakespeare's canon, the play remains in many ways a curiosity, locked within the circumstances of its original composition and trapped by the fears of its historical moment.

4 More's speech to the rioting Londoners has nevertheless become a free-floating but culturally powerful instance of fear of others. "It might have been written yesterday, might it not?" asked John Dover Wilson in a 1938 lecture, printed in a 1962 book. ${ }^{7}$ Perhaps the speech might have been written in all our yesterdays. Samantha Power, then American ambassador to the United Nations, applied it to contemporary events in 2016: "The 'wretched strangers' have changed of course," Power admitted, "from the Lombards targeted in 1517 in those riots to the Huguenot refugees in Shakespeare's time and to the Syrians, Iraqis, South Sudanese, Eritreans and others fleeing repressive governments of our time." ${ }^{8}$ Sir Ian McKellen, the first professional actor to perform the title role, has delivered the speech several times as an independent monologue, including in response to a horrifying gay-bashing incident close to the place in London where the historical More would have met the rioters. McKellen first sets the scene, explaining that the crowd makes

the usual complaint about strangers, immigrants, odd people, queers. They behave differently from the rest of us, and they look different and they eat our food and take our jobs. You know: send them back where they came from. Get rid of them. Stamp of their heads, even. ${ }^{9}$

5 This is hardly the only speech by Shakespeare to be habitually torn from the context for which it was written. Ulysses' speech about degree in Troilus and Cressida would provide another example. ${ }^{10}$ Indeed, R. W. Chambers argued for Shakespeare's authorship of the three pages in Hand D on the grounds that this passage echoes the support for authority in Troilus and Cressida. ${ }^{11}$ Where Ulysses' speech defends hierarchy, however, More's speech has assumed new life as a free-standing call to tolerance. In Power's reading, the call to tolerance extends from the immigrants --- mostly Lombards and French --- against whom the Ill May Day riots were directed five hundred years ago, to the Huguenots who were victims of riots closer to the time of the play's composition, and to the many immigrants who suffer discrimination and violence today. McKellen extends this further, from immigrants to gays and, by extension, any sort of "other."

6 The passage may be taken out of context so easily, in part because its relation to any period is imprecise. To begin with, it commits historical inaccuracy. If Holinshed is to be believed, not only did More fail to quell the crowd, but one Nicholas Downes who 
accompanied him as a sergeant at arms incited its members to greater violence by his angry response to being attacked. ${ }^{12}$ Shakespeare may have altered historical events to reflect those in his own time. He did, after all, live with a refugee Huguenot family, the Mountjoys, as Charles Nicholl details wonderfully in The Lodger Shakespeare: His Life on Silver Street. ${ }^{13}$ Honigmann describes several of Shakespeare's immigrant connections, including the wife of his publisher, Richard Field; Peter Street, builder of the Globe theatre; Gheerart Janssen, the stonecutter responsible for the bust on Shakespeare's monument; and Martin Droeshout, engraver of the famous image of the writer in the first folio. ${ }^{14}$ For that matter, Shakespeare himself might have been considered an internal migrant, from Warwickshire. Margaret Tudeau-Clayton suggests that this outsider perspective may have recommended him to the other writers of the play. ${ }^{15} \mathrm{He}$ nevertheless follows Tilney's lead in not referring to French immigrants, and so distances his version of the speech from recent events. ${ }^{16}$ In any case, there is no reason to connect English xenophobia with any particular eruption of violence. According to Laura Hunt Yungblut,

actual attacks, anticipated attacks, or investigations of threatening materials (such as anti-alien pamphlets or broadsheets) are recorded for 1493, 1517, 1573, 1575, $1581,1583,1586,1587,1593$, and 1595; and native or foreign dignitaries from the 1460 s to the 1610s wrote eloquently and consistently about the English people's xenophobia. ${ }^{17}$

7 Even if we must tie the play to contemporary issues or attitudes, there is little reason to think it a covert reference to particular contemporary events. Nor should we make too much of parallels to refugee crises of our own time. In spite of Power's parallel between the strangers in the play and refugees of today, the strangers in the first scene are not, in fact, "fleeing repressive governments." On the contrary, they flaunt their ability to appeal to royal authority through their own ambassador, and therefore claim the protection, formal or actual, of two governments: "My Lord Ambassador shall once more make your Mayor have a check if he punish thee not for this saucy presumption," Francis de Barde sneers at George Betts (1.41-44). John Jowett notes that

The insurrection relates strongly to current concerns about urban unrest and relations between indigenous and historically immigrant communities, but the cultural politics are disconcerting to a modern audience and the theme has run its course before the play is halfway through. ${ }^{18}$

8 It is always worthwhile to historicize, but Shakespeare's contribution to the play addresses issues beyond the immediate historical context and which do not comfortably map unto ours. Neither historicism nor presentism accounts for the importance of More's speech. On the contrary, the Hand D passage has relevance to the time it purports to describe, to our own time, to Dover Wilson's time, and to the time of its composition because it raises broad, ethical questions.

9 The passages ascribed to Shakespeare distinguish themselves from the rest of the play not only in their imagery and handwriting, but also in their presentation of the strangers. Tudeau-Clayton notes that "represented in the opening scenes as predatory and profiteering abusers of privilege, they are represented by 'Hand D' rather as scapegoats and victims of exclusionary violence." ${ }^{19}$ More's "verbal image of the 'wretched strangers," Sabine Schülting notes, is "diametrically opposed to their previous appearance on stage." ${ }^{20}$ The first scene of the play, written by Munday, justifies the London mob's fear of strangers. Even before the play was written, Edward Hall, in his chronicle of the events, asserted that "...the straungers were so proude, that 
they disdayned, mocked and oppressed the Englishmen, which was the beginnynge of the grudge." ${ }^{21}$ Raphael Holinshed follows Hall closely enough as to be accused of plagiarism if he did not cite Hall, albeit with the addition of marginal notes, such as "The insolent sawcinesse of the Frenchmen against the English," and "The diuelish malice of the Frenchmen." ${ }^{22}$ Had the play been performed, the audience would have first been greeted by the spectacle of de Barde attempting to abduct Doll Williamson: "Thou art my prize," he claims, "and I plead purchase of thee" (1.2-3). The early scenes of the play dramatize events from the chronicles, in which the foreigners function as other in the sense of being objects of fear.

One may be more specific: the foreigners pose an existential threat, and therefore constitute an enemy in the sense used by Carl Schmitt, a threat sufficient to unite Londoners against them. Schmitt argues that "Every religious, moral, economic, ethical, or other antithesis transforms into a political one if it is sufficiently strong to group human beings effectively according to friend or enemy." ${ }^{23}$ Moreover, this derivation gives politics a bellicose and existential character: "War follows from enmity. War is the existential negation of the enemy." ${ }^{24}$ Such enmity, Schmitt is careful to clarify, can be reduced neither to aesthetics nor to morality. No group need consider its enemy ugly or evil in order to view it as an existential threat. "The enemy in the political sense," Schmitt specifies, "need not be hated personally." ${ }^{25}$ Indeed, Schmitt objected to the whole idea of fighting on behalf of humanity, for this transforms the enemy into "a monster that must not only be defeated but also utterly destroyed."26 Though written in 1932, this attack on what would later be understood as international humanitarian law served Schmitt later, when he "impugned the legitimacy" of the Nuremberg trials, to which he was nearly summoned as a defendant. ${ }^{27}$ Schmitt argues that "The definition of the political suggested here neither favors war nor militarism, neither imperialism nor pacifism." ${ }^{28}$ Nevertheless, enmity defines the state for Schmitt and hence defines politics. The injunction to love our enemies, he insists, applies only to the private sphere. "It certainly does not mean that one should love and support the enemies of one's own people." ${ }^{29}$ To Schmitt, we are not known, as in Christianity, by our loves, but by our enmities.

11 Initially, the strangers do indeed reveal themselves as an existential threat, the external enemy that defines a people. Cavaler takes food from Williamson, stealing his doves, and the citizens complain that "strangers eat the bread from the fatherless children" (1.123). In the first scene, the foreigners attack Londoners, not vice versa. They are also, however, an existential threat in a sense other than mortal. By successfully appropriating London women, they unman the Londoners, robbing them of identity. In the play as in the chronicles, their predations threaten the city itself. The goldsmith whose wife is seduced away from him represents the city corporation. In case anyone could miss the point, de Barde specifies that "an she were the Mayor of London's wife, had I her once in my possession I would keep her in spite of him that durst say nay" (1.53-55). The Londoners' first act of rebellion -- or, they would no doubt insist, resistance -- is to prevail upon one Doctor Beal to publish a list of their grievances from the pulpit as part of the annual Spittals sermons. This complaint describes Londoners as victims exclusively, drawn into solidarity by their shared victimhood:

For so it is that aliens and strangers eat the bread from the fatherless children, and take the living from all the artificers, and the intercourse from all the merchants, whereby poverty is so much increased that every man bewaileth the misery of 
other; for craftsmen be brought to beggary, and merchants to neediness. Wherefore, the premises considered, the redress must be of the commons knit and united to one part. (1.123-130)

12 As Lincoln notes before reading it, "You shall perceive there's no hurt in the bill" (1.114-115). It establishes the Londoners as victims of a mortal threat, and calls them to unity.

13 Their position as victims is no sooner established, however, than they plot to become oppressors themselves. Betts immediately moves to raising a rebel army of what he calls "friends enough, whose names we will closely keep in writing, and on May Day next in the morning we'll go forth a-Maying, but make it the worst May Day for the strangers that ever they saw" (1.140-144). A plan to attack the strangers expresses the rebels' solidarity: "My masters," Williamson suggests with egalitarian zeal, "ere we part let's friendly go and drink together, and swear true secrecy upon our lives" (1.149-151). As Betts's phrasing indicates, the rebellion draws its participants together into a group of friends. The rebellion includes women, most notably the character Doll who, in contrast to her homonym in Henry IV, Part 2, is not a prostitute, but a faithful wife resisting de Barde's rapine advances. ${ }^{30}$ After the failure of the rebellion, she touchingly asks to be executed first: "You know not what a comfort you shall bring / To my poor heart to die before my husband" (7.80-81). Doll is the first to subscribe to Betts's list of supporters, promising to "make a captain among ye" (1.147). Indeed, the position of women as outside the law may recommend them as rebels: "If our husbands must be bridled by law," Doll informs the strangers, "their wives will be a little lawless, and soundly beat ye" (1.74-76). The rebellion shows itself internally egalitarian, but the rebels' egalitarian community relies on the distinction of friend and enemy so important to Schmitt's theory of the political. Its internal solidarity is merely the inverse of its violence against outsiders.

The setting, class context and characters change in the next scene but without breaking thematic continuity, in that both scenes broach the question of who should be considered a victim, and whether victims are to be blamed. The second scene introduces the title character as a member of the Court of Sessions and shows him tricking a Justice Suresby into showing his own hypocrisy. Suresby accuses Smart, the victim of a convicted pickpocket, of bringing the theft upon himself: "What makes so many pilferers and felons / But such fond baits that foolish people lay / To tempt the needy miserable wretch?" (2.31-33). More, in turn, arranges for Lifter, the aptly-named pickpocket, to obtain Suresby's purse, then repeats his own words back to him (2.175-177). Over the course of the first seven scenes, the Londoners transform from victims to oppressors then back to victims, with a speed that might induce vertigo in the audience, had there been one. As previously noted, Betts promises to "make it the worst May Day for the strangers that ever they saw" (1.142-144), but soon Lincoln warns the rebels that they must escape, "Lest this prove to us an ill May Day" (4.78-79). For much of the execution scene, the rebels seem to have been cheated by More's promise to obtain their pardons. Doll remarks that "had't not been for his persuasion, / John Lincoln had not hung here as he does" (7.92-93). Pathetically, she commends her young children to "the love of some good honest friend / To bring them up in charitable sort" (7.117-118). In what promises to be her last speech, she reaffirms her solidarity with the other rebels, and returns to the threat of rape, which she escapes even in death: "when I am dead, for me yet say / I died in scorn to be a stranger's prey" (7.130-131). A pardon arrives suddenly, with Surrey explaining that "Sir Thomas More 
humbly upon his knee / Did beg the lives of all" (7.144-145). These lines provide another historical inaccuracy, but they also culminate the transformation of the rebels back into victims, or at least potential victims.

The clown, in particular, adds a note of manic anarchy to the rebellion. He reverses the threat of rape, declaring skeltonically,

Now Mars for thy honour,

Dutch or French,

So it be a wench,

I'll upon her. (4.53-56)

The same character calls on the rebels to "Use no more swords, / Nor no more words, / But fire the houses" (4.33-35). Sherwin immediately recognizes that such a pyrotechnical tactic "would much endanger the whole City" (4.41). The danger of fire would be obvious to an early modern audience, who lacked the means to effectively fight it. "Next to plague," writes Keith Thomas, "perhaps the greatest single threat to security was fire." ${ }^{11}$ The scene nevertheless ends with a call to "Burn down their kennels" (4.78), in hopes of causing enough distraction to cover a retreat. At the beginning of scene five, the hard-pressed representatives of law and order receive a report from Sir John Munday, saying that he was attacked by "A sort of prentices playing at cudgels" whom he fears "are gone to join / With Lincoln, Sherwin and their dangerous train" $(5.3,5.7-8)$. The reader meets these apprentices, boasting of their fighting skill, in a scene removed in the course of revision. ${ }^{32}$ We soon hear that the rebels have freed prisoners from Newgate, "Both felons and notorious murderers, / Who desperately cleave to their lawless train" (5.21-22). The rebellion increasingly unites all forces of disorder and mayhem under its own banner. It also gathers strength from ignorance. In the next scene, Lincoln accuses the foreigners: "They bring in strange roots, which is merely to the undoing of poor prentices. For what's a sorry parsnip to a poor heart?" (6.11-13). The play shifts rapidly from sympathy with a popular movement, achieving its own, egalitarian organization, and pitting itself against the oppression of an international elite, to fear of a recklessly ignorant and destructive populism. Whereas the version of the Spittals sermon read by Lincoln presents the London rebels as objects of pity, they become a serious threat to the foreigners, order in general and even themselves. They become, in other words, objects of fear.

In one of his final public presentations, accepting the Kluge Prize by webcast, Paul Ricoeur addresses the role of fear in founding the social contract:

The myth of the state of nature accords to competition, to defiance, to the arrogant affirmation of solitary glory, the role of foundation and of origin. In this war of all against all, the fear of violent death would reign supreme. This pessimism concerning the ground of human nature goes hand-in-hand with praise of the absolute power of a sovereign who remains outside the contract of submission made by citizens delivered from fear. ${ }^{33}$

The historical and the fictive More lived and were written before Thomas Hobbes started publishing. Nevertheless, the play's title character anticipates the description of the state of nature in The Leviathan, when he claims that "men, like ravenous fishes, / Would feed on one another" (6.97-98). More proclaims the importance of peace to the well-being of the rioting Londoners:

Look what you do offend you cry upon;

That is, the peace. Not one of you here present, 
Had there such fellows lived when you were babes

That could have topped the peace as now you would,

The peace wherein you have till now grown up

Had been ta'en from you, and the bloody times

Could not have brought you to the state of men. (6.71-77)

Despite anticipating the myth of the state of nature, More does not anticipate the theory of the social contract, for he does not found his argument on the Londoners' fear for themselves. They certainly express none in answer, continuing to protest that they wish to see "the removing of the strangers, which cannot choose but much advantage the poor handicrafts of the City" (6.80-82). Moreover, More does not show the rebels that they would suffer in a renewed state of nature. The use of the past conditional, describing what would have been the case in other circumstances, compounds the awkwardness of the second sentence above, though the stranded phrase with which it begins hardly aids comprehension. More refers to the past, but to a past already delivered from a state of nature and which only hypothetically might once have returned to it, "Had there such fellows lived when you were babes." Rather than calling on his audience to fear a return to anarchy, More here demonstrates the logical priority of peace. The Londoners had to have lived in a state of peace in order to live at all, and therefore foment violence. Even rebellions, More argues, require internal peace, if they are to entertain any chance of succeeding: "Why, even your hurly," he explains, "Cannot proceed but by obedience" (6.128-129). Rebellion depends on the very order which it undermines: "What rebel captain, / As mutinies are incident, by his name / Can still the rout? Who will obey a traitor?" (6.130-132). The Homily against Disobedience and Willful Rebellion treats the breakdown of social order as a violation of doctrine and a threat to the rebels themselves, who will certainly be punished. It cites Romans 13, quoting "there is no power but of GOD, and the powers that be, are ordeined of GOD. Whosoeuer therefore resisteth the power, resisteth the ordinance of GOD, and they that resist, shall receiue to themselues damnation." ${ }^{34}$ More refers to the same passage when he declares that "'tis a sin / Which oft th'apostle did forewarn us of, / Urging obedience to authority" (6.105-107). Honigmann notes that "No one can fail to observe the dramatic irony when Sir Thomas preaches obedience to the King as the gospel of good citizenship." 35 Surrey reverses the irony: "'Tis strange," he observes, "that my Lord Chancellor should refuse / The duty that the law of God bequeaths / Unto the king" (10.105-107). More makes a conventional argument for divine right but events later in the play ironize it. The homily also threatens, calling to mind "the histories of olde, as also of latter rebellions, in our fathers, and our fresh memorie" in which

are recorded withall to perpetuall memorie, the great and horrible murders of infinite multitudes and thousands of the common people slaine in rebellion, dreadfull executions of the authours and captaines, the pitifull vndoing of their wiues \& children, and disinheriting of the heyres of the rebels for euer [...] with the finall ouerthrow, and shamefull deaths of all rebels. ${ }^{36}$

More follows this logic later in his speech to the rebels, implicitly threatening when he calls on them to imagine their own short and brutal lives in exile, hinting further that they deserve worse, though the king might "come too short of your great trespass / As but to banish you" (6.140-141). More does appeal to the self-interest of the Londoners in calling for them to submit to the king's mercy and avoid an anarchy which would be destructive in itself, as well as inevitably invite retribution. In addition and less 
conventionally, however, he treats rebellion as a sort of absurdity, a logical impossibility or contradiction in terms.

21 As strikingly, More appeals to the rebels' concern for others, at least as much as he appeals to their self-interest or fear for their souls, and before he does so. "Grant them removed," he begins: "Imagine that you see the wretched strangers, / Their babies at their backs, with their poor luggage, / Plodding to th' ports and coasts for transportation" $(6.83 ; 6.85-87)$. By "transportation," More probably does not mean "Removal or banishment, as of a criminal to a penal settlement," as this use is not witnessed by the Oxford English Dictionary until 1669. ${ }^{37}$ Quite apart from such philological concerns, the definition cannot apply because More does not criminalize the strangers, but treats them as objects of pity and concern. In More's appeal, the strangers cease to constitute an existential threat which wields the rebels into a popular movement, and instead become something much more like the Other described by Levinas, ${ }^{38}$ who "can present himself as a stranger without opposing me as obstacle or enemy. ... The Other who dominates me in his transcendence is thus the stranger, the widow, and the orphan, to whom I am obligated." ${ }^{39}$ In "Diachrony and Representation," Levinas argues that the alterity of the Other elicits

fear of all the violence and usurpation that my existing, despite the innocence of its intentions, risks committing. The risk of occupying --- from the moment of the $D a$ of my Dasein --- the place of an other and thus, on the concrete level, of exiling him, of condemning him to a miserable condition in some 'third' or 'fourth' world, of bringing him death. ${ }^{40}$

Only after establishing his image of the strangers as refugees, does More proceed to point out the consequences to the rebels of destroying order: "by this pattern / Not one of you would live an aged man" (6.93-94). His reasoning begins with the suffering of an Other, before turning to how his audience would themselves suffer. He makes a similar argument later in the speech. "You'll put down strangers, / Kill them, cut their throats, possess their houses [?]" he asks rhetorically, before pointing out that his audience are themselves under threat of banishment and if it came about, "Why, you must needs be strangers" (6.135-137; 6.146). This seems like a Biblical argument for sympathy: "But the stranger that dwelleth with you, shall be as one of yourselves, and thou shalt love him as thyself: for ye were strangers in the land of Egypt: I am the Lord your God." ${ }^{41}$ The crowd, clearly inspired as much by Matthew's Gospel as by More's appeal, answers him by crying "Let's do as we may be done by" (6.157-158)..$^{42}$ Where the Old Testament injunction refers to a previous experience of being strangers, however, More does not start with the suffering of his audience, and ask them to compare the suffering of strangers to their own. On the precise contrary, their hypothetical exile is to be understood by reference to "the strangers' case." Fear for the other precedes and serves as a model of fear for the self. At least at this point, More inverts the logic of the social contract. He accepts "the myth of the state of nature," as a terrifying primordial anarchy, and indeed accuses the rioters of "mountainish inhumanity" (6.156). Instead of imagining a state in which everyone would fear for herself or himself, however, More imagines a situation in which everyone would fear for other people. The crowd is called to feel what Levinas calls "Fear for the other, fear for the death of the other man" which is "my fear, but it is in no way a fear for oneself." ${ }^{43}$ More's speech calls for a recognition of the Other as "the stranger, the widow, and the orphan."

23 Schülting notices something similar, arguing that More -- and, by extension, Shakespeare -- calls on the characters on stage, but also the audience "imaginatively to 
cross the gap not merely between fiction and reality, but also between their own and another's experiences." ${ }^{44}$ In this instance, the rioters are calmed by "More's appeal to their empathy with the migrants." Specifically, they are asked to imagine themselves as exiles. "More's vision," Schülting argues, "places the exiles in a condition reminiscent of Lear's situation on the heath; excluded from all society, reduced to bare existence, and denied not merely the status of citizens but even that of human beings." ${ }^{25}$ I have argued elsewhere, however, that Lear's sudden access to concern with the "poor naked wretches" does not follow from his exposure "to feel what wretches feel." ${ }^{46}$ On the contrary, his recognition of his own situation follows recognition of others, starting with the Fool. ${ }^{47}$ "I should e'en die with pity," says Lear when he awakens with Cordelia, "To see another thus." ${ }^{38}$ Self-pity follows concern for others --- even hypothetical or imagined others --- to whom one's own position can then be compared. Similarly, in Shakespeare's additions to Sir Thomas More, the rioting Londoners are not called to care for the strangers by comparing "the strangers' case" to their own, which they would first care about in the manner of self-interested agents. Before being asked to imagine themselves becoming exiles, they are asked to imagine the suffering of "the wretched strangers."

24 For that matter, the Spittals sermon describes the suffering of Londoners as producing a situation "whereby poverty is so much increased that every man bewaileth the misery of other" (1.126-27). The Londoners unite murderously against strangers as a Schmittian enemy, but first they care for and fear for one another. The Levinasian Other, as a call to responsibility, precedes the Schmittian enemy, opposition to whom constitutes the state and hence the political, in Schmitt's understanding of the term. On the other hand, instead of founding politics and hence the state on the distinction of friend and enemy, Levinas claims that the state's "necessity is ethical --- indeed, it's an old ethical idea which commands us precisely to defend our neighbours." Speaking in this instance in the shadow of accusations of Israeli collusion in massacres at Lebanese refugee camps, he adds that "there is also an ethical limit to this ethically necessary political existence." ${ }^{49}$ Without some concern for other people, even Schmitt's concept of the political makes little sense, for the threat posed by the enemy would not inspire the foundation of a state except by eliciting concern for others. As importantly, this ethical prompting not only helps to found the state, but also describes its limits.

The first book of the historical Thomas More's Utopia presents a debate over the question of whether the scholar has an obligation to participate in the world of politics. Raphael Hythlodaeus asserts to More's fictive alter ego that public service is futile, whereas the character More retorts that "This is the most important part of your duty, as it is of every good man." ${ }^{50}$ The author entered royal service, faithful to the advice of his own namesake and creation, but with mortal and martyrological results. The fictive More of the play also struggles with this issue in a soliloquy at the beginning of scene eight, in which he attempts to maintain his humility, whilst recognizing the danger of his public position. In scene ten, however, we find More rather cynically suggesting that the king employ the Holy Roman Emperor as a mercenary: "Then, to prevent in French wars England's loss, / Let German flags wave with our England's cross" (10.66-67). He seems, in other words, to have sold out his pacifist principles for royal service. His respect for royal power, however, is less than absolute. On the contrary, as he shows in calming the crowd, fealty to royal power follows from a more basic commitment to the good of others. Faced with the articles to be signed, he demurs: "Our conscience first shall parley with our laws" (10.73). More becomes politically 
active --- indeed he seems at this point to adopt a royal "we" as his own --- but power is not, for him, an absolute end.

It is a platitude of contemporary criticism that everything is political, but it is not clear what this means. Many thinkers in the western tradition ascribe a commanding position to violent struggle, to war as "the father and king of all things," as Heraclitus said. ${ }^{51}$ Both Schmitt and Michel Foucault reverse Carl von Clausewitz's dictum that war is the continuation of politics by other means, to turn politics into a continuation of war. ${ }^{52}$ So does John Yoo, a lawyer whose career is principally remembered for coauthoring the so-called "torture memos" which justified the use of waterboarding on suspected terrorists. ${ }^{53}$ Which of these figures one finds most disconcerting may perhaps serve as a litmus-test of one's own loyalties, but all agree that politics grows from war, from the struggle against an existential threat in which, as in Ricoeur's description of the state of nature, "the fear of violent death would reign supreme." Such a politics proves, I argue, inadequate both to our fears and to our relations with other people. The spectre of a common enemy draws the London rebels in Sir Thomas More into solidarity, but even this enmity depends on an earlier concern with one another. In shifting from a depiction of the strangers as threatening enemies, to an image of them as themselves threatened, Shakespeare's More introduces a new basis of the political, more primitive than the fear which would reign supreme in social contract theory or the divine right theory of his own time. Fear inspires his politics, but it is a fear for others at least as much as a fear for himself.

\section{NOTES}

1. Anthony Munday et al., Sir Thomas More, ed. John Jowett, coll. Arden Shakespeare, London and New York, Bloomsbury, 2011, Tilney.1-6. Further references to the play will be to this edition, and indicated in parentheses. References to the critical apparatus will appear in the notes, but under Jowett's name.

2. E. A. J. Honigmann, "Shakespeare, Sir Thomas More and Asylum Seekers", Shakespeare Survey 57, 2004, 225-235, p. 233.

3. Idem, p. 226.

4. Eric Griffin, "Shakespeare, Marlowe and the Stranger Crisis of the Early 1590s", Shakespeare and Immigration, Ashgate, 2014, 13-36, p. 22, 23.

5. Jowett, p. 108.

6. Idem, p. 465.

7. Shakespeare's Happy Comedies, London, Faber and Faber, 1962, p. 111.

8. A transcript of Dr. Power's speech at the Lincoln Center Global Exchange in New York on September 16, 2016 is archived by the United States Mission to the United Nations at https:// 2009-2017-usun.state.gov/remarks/7434, last accessed 10 April 2017.

9. The entire, largely autobiographical, speech to the Cambridge Union can be found on Youtube. The relevant clip begins a little after an hour and three minutes into the speech. https:// youtu.be/SpMAM-Qc-6Q?t=1h3m58s, last accessed 8 April 2017. 
10. Most famously in E. M. W. Tillyard, The Elizabethan World Picture, London, Chatto and Windus, 1943, p. 7 ff. (accessible online at https://archive.org/details/in.ernet.dli.2015.531693, last accessed 15 April 2017).

11. William H. Matchett, "Shylock, Iago, and Sir Thomas More: With Some Further Discussion of Shakespeare's Imagination”, PMLA 92.2, 1977, 217-230, p. 218.

12. Reproduced in an appendix by Jowett, op cit., p. 478.

13. New York, Viking, 2008.

14. Honigmann, op. cit. pp. 233-234.

15. Margaret Tudeau-Clayton, “'This is the Strangers' Case': The Utopic Dissonance of Shakespeare's Contribution to Sir Thomas More", Shakespeare Survey 65, 2013, 239-254, p. 244.

16. Jowett, op. cit., p. 46

17. Laura Hunt Yungblutt, Strangers Settled Here Amongst Us: Policies, Perceptions and the Presence of Aliens in Elizabethan England, London and New York, Routledge, 1996, p. 40.

18. Jowett, op cit, p. 120.

19. Tudeau-Clayton, op. cit., p. 246.

20. Sabine Schülting, “'What Country, Friends, Is This?' The Performance of Conflict in Shakespeare's Drama of Migration", Shakespeare and Conflict: A European Perspective, New York, Palgrave Macmillan, 2013, 24-39, p. 29.

21. The vnion of the two noble and illustre famelies of Lancastre [and] Yorke, London, Richard Grafton, 1548, p. lix verso (document image 436), STC 12722, last accessed (via EEBO) 8 April 2017.

22. Reproduced as an appendix by Jowett, op. cit., pp. 473-474.

23. The Concept of the Political, trans. George Schwab, New Brunswick, Rutgers University Press, 1976, p. 37.

24. Idem, p. 33.

25. Idem, p. 29.

26. Idem, p. 36

27. Lars Vinx, "Carl Schmitt", The Stanford Encyclopedia of Philosophy (Spring 2016 edition), ed. Edward N. Zalta, (accessible online at http://plato.stanford.edu/archives/spr2016/entries/ schmitt/, last accessed 8 April 2016.

28. Op. cit., p. 33.

29. Op. cit., p. 29.

30. Jowett, op. cit., p. 30.

31. Religion and the Decline of Magic: Studies in Popular Beliefs in Sixteenth- and Seventeenth-Century England, London, Penguin Books, 1971, p. 17.

32. Op. cit., Appendix 1, OT1b.

33. Paul Ricoeur, "Accepting Personal Capacities and Pleading for Mutual Recognition", Library of Congress Webpage, 2014, accessible online at https://www.loc.gov/loc/kluge/prize/ricoeurtranscript.html, last accessed 8 April 2017.

34. "Homily against Disobedience and Wilful Rebellion", Renaissance Electronic Texts, ed. Ian Lancashire, reproduces STC 13675, II.2.1.87-1-90, accessible online at www.library.utoronto.ca/ utel/ret/homilies/bk2hom21.html, last accessed 8 April 2017.

35. E. A. J. Honigmann, "The Play of Sir Thomas More and Some Contemporary Events", Shakespeare Survey: An Annual Survey of Shakespeare Studies and Production 42, 1990, 77-84, p. 78.

36. Op. cit., II.2.1-1041-1048.

37. "Transportation," noun., 2c.

38. Translators of Levinas by convention capitalize "Other" when they translate the French "autrui," which Levinas uses to designate the Other as an ethical command from the merely logical other, as in "X is other than Y." The former is, of course, the sort of Other most fully distinguished from the other designated by Schmitt as the enemy. Alphonso Lingis explains his establishment of this convention, whereas Dino Galetti decries it. Emmanuel Levinas, Totality and 
Infinity: An Essay on Exteriority, trans. Alphonso Lingis, Pittsburgh, Duquesne University Press, 1969, pp. 24-25, footnote. Dino Galetti, “The grammar of Levinas' other, Other, autrui, Autrui: Addressing translation conventions and interpretation in English-language Levinas studies", South African Journal of Philosophy 34, 2, 2015, 199-123.

39. Totality and Infinity, p. 215.

40. "Diachrony and Representation," Entre Nous, trans. Michael B. Smith and Barabra Harshav, New York, Columbia University Press, 1998, 159-177, p. 169.

41. Leviticus 19.34, Geneva Bible, http://www.biblegateway.com, last accessed 14 April 2017.

42. Matthew 7.12.

43. "From the One to the Other: Transcendence and Time", Entre Nous, trans. Michael B. Smith and Barabra Harshav, New York, Columbia University Press, 1998, 133-153, p. 146.

44. Schülting, op. cit., p. 37.

45. Idem, p. 29.

46. William Shakespeare, King Lear, ed. R A. Foakes, coll. Arden Shakespeare, $3^{\text {rd }}$ edition, London, Thomas Nelson, 2000, 3.4.28, 3.4.34.

47. Sean Lawrence, Forgiving the Gift: The Philosophy of Generosity in Shakespeare and Marlowe, Pittsburgh, Duquesne University Press, 2012, pp. 101-103.

48. King Lear, 4.7.53-54. These words appear as an epigraph at the beginning of Emmanuel Levinas, Humanism of the Other, trans. Nidra Poller, Urbana and Chicago, University of Illinois Press, 2003, p. 3.

49. "Ethics and Politics", The Levinas Reader, Oxford, Blackwell, 1989, 289-297, p. 292-293.

50. Thomas More, Utopia, ed. William P. Weaver, trans. G. C. Richards, A Broadview Anthology of British Literature Edition, Peterborough (Ontario), Broadview Press, 2010, p. 46.

51. K. R. Popper, The Open Society and Its Enemies, vol. 1, The Spell of Plato, New York, Harper Torchbooks, 1962, p. 16.

52. Schmitt, op. cit., p. 34-35; Michel Foucault, "Truth and Power”, The Foucault Reader, ed. Paul Rabinow, New York, Pantheon Books, 1984, 58-75, p. 64-65.

53. He entitles his autobiography War by Other Means: An Insider's Account of the War on Terror. It is mentioned by David Luban, "Carl Schmitt and the Critique of Lawfare", Case Western Reserve Journal of International Law, 43, 1, 2010, 457-471, p. 457.

\section{RÉSUMÉS}

Le drame Sir Thomas More, écrit à plusieurs mains, comprend une scène Shakespearienne dans laquelle le personnage éponyme apaise une foule xénophobe de Londoniens, qui s'en prend aux étrangers. L'appel de More inspire à la foule une crainte pour l'étranger, au lieu d'une crainte de l'étranger. Bien qu'il puisse se placer dans le context historique de More, celui de Shakespeare ou du nôtre, le discours de More pose une série de questions plus larges sur l'importance d'autrui et sur la politique. On peut utiliser ce discours pour contredire les vues de Carl Schmitt pour qui l'autre est ennemi et la politique résulte de la menace de guerre. De même, on peut utiliser ce discours pour défendre la philosophie d'Emmanuel Levinas selon laquelle l'autre appelle à la responsabilité, et la politique est inspirée par le souci de l'autre.

The collaborative play Sir Thomas More includes a scene written by Shakespeare in which the title character calms a xenophobic mob of Londoners, bent on attacking "strangers." More's appeal to 
the crowd inspires in them a fear for the strangers replacing their earlier fear of the strangers. Although it can be placed within More's historical context, Shakespeare's context, or ours, the speech opens a series of broader questions about the importance of the other and the nature of politics. It can be used to argue against Carl Schmitt's view of the other as enemy, and of politics as proceeding from the possibility of war, in favour of Emmanuel Levinas's view of the other as a call to responsibility, and of politics as inspired by a concern for others.

\section{INDEX}

Mots-clés : Immigration, Paix, Rébellion, Réfugiés, Carl Schmitt, William Shakespeare, Guerre, Xénophobie

Keywords : Immigration, Peace, Rebellion, Refugees, Carl Schmitt, William Shakespeare, War, Xenophobia

\section{AUTEUR}

\section{SEAN LAWRENCE}

University of British Columbia, Okanagan 